\title{
Anaerobiospirillum thomasii sp. nov., an Anaerobic Spiral Bacterium Isolated from the Feces of Cats and Dogs and from Diarrheal Feces of Humans, and Emendation of the Genus Anaerobiospirillum
}

\author{
HENRY MALNICK* \\ Laboratory of Hospital Infection, Central Public Health Laboratory, \\ London NW9 5HT, United Kingdom
}

\begin{abstract}
Thirty-seven similar strains isolated from feces of cats and dogs and from human diarrheal feces had characteristics of the genus Anaerobiospirillum. These organisms were distinguished from the only previously described Anaerobiospirillum species, Anaerobiospirillum succiniciproducens, by producing acid from adonitol but not from fructose, raffinose, or sucrose and by the lack of $\alpha$-glucosidase. The $G+C$ contents of the DNAs of the new strains were 39 to $42 \mathrm{~mol} \%$. The results of morphological, physiological, DNA G+C content, and DNA homology studies support the proposal that the description of the genus Anaerobiospirillum should be emended so that a new species can be included in the genus. The new species Anaerobiospirillum thomasii is proposed, with strain A273/88 (= NCTC 12467) as the type strain.
\end{abstract}

The genus Anaerobiospirillum, containing the single species Anaerobiospirillum succiniciproducens, was described by Davis et al. in 1976 (1) as a genus of anaerobic spiral bacteria with bipolar tufts of flagella. Later, $A$. succiniciproducens was implicated as a cause of human bacteremia (5). In 1983 Anaerobiospirillum-like organisms were isolated from two patients with diarrhea (2). This led to further studies which demonstrated that both $A$. succiniciproducens and Anaerobiospirillumlike organisms are part of the normal fecal flora of cats and dogs and that Anaerobiospirillum-like organisms may cause diarrhea in humans (3).

In this study I compared the phenotypic characteristics, DNA base compositions, and levels of DNA-DNA homology of Anaerobiospirillum-like organisms and A. succiniciproducens. I propose that the description of the genus Anaerobiospirillum be emended so that a new species, Anaerobiospirillum thomasii, can be included in the genus.

\section{MATERIALS AND METHODS}

Strains examined and media. The strains used in this study are listed in Table 1. The human strains were isolated during routine diagnostic examination of blood and fecal samples. Details concerning the clinical strains and the methods of isolation used for animal and human strains have been described previously (3).

All strains were grown on fastidious anaerobe agar (Lab M, Topley House, Bury, England) with added horse blood $(50 \mathrm{ml} / \mathrm{liter})$ and were incubated at $37^{\circ} \mathrm{C}$ in a Don Whitley Mark III anaerobic cabinet.

Cell morphology and tests for biochemical properties. The procedures used to determine cell morphology, carbohydrate fermentation, substrate hydrolysis (as determined by the API ZYM technique), and volatile and nonvolatile acid end products of glucose fermentation (as determined by gas chromatography) have been described previously (3). For electron microscopy $1 \%$ formalin was added to a $24-\mathrm{h}$ broth culture. The suspension was negatively stained with $1 \%$ phosphotungstic acid ( $\mathrm{pH}$ 6.5), and grids were examined with a Philips model 420 transmission electron microscope.

DNA base composition. DNA was extracted and prepared from 48-h plate cultures (11). The guanine-plus-cytosine $(\mathrm{G}+\mathrm{C})$ contents of the DNAs of four strains of $A$. succiniciproducens and 13 strains of the Anaerobiospirillum-like organism were determined by the thermal denaturation method (4). Escherichia coli type strain NCTC 9001 was used as a reference as it has a known $\mathrm{G}+\mathrm{C}$ content of $51.1 \mathrm{~mol} \%$ (8)

DNA-DNA hybridization. RNA-free DNA was extracted by using a combination of the methods of Owen and Borman (7) and Pitcher et al. (11). Cells were

\footnotetext{
* Phone: (0181) 200-4400. Fax: (0181) 200-7449.
}

removed from plates and suspended in $240 \mu \mathrm{l}$ of RNase/SET ( $50 \mathrm{mg}$ of RNase A per $\mathrm{ml}$ in SET buffer [ $150 \mathrm{mM} \mathrm{NaCl}, 15 \mathrm{mM}$ EDTA, $60 \mathrm{mM}$ Tris- $\mathrm{HCl}$; final $\mathrm{pH}, 8.3 \mathrm{~J}), 10 \mu \mathrm{l}$ of $25 \%$ sodium dodecyl sulfate was added, and the mixture was incubated in a $37^{\circ} \mathrm{C}$ water bath for $30 \mathrm{~min}$. After incubation, $250 \mu \mathrm{l}$ of GES reagent $(60 \mathrm{~g}$ of guanidium thiocyanate, $3.7 \mathrm{~g}$ of EDTA, and $1.7 \mathrm{ml}$ of $30 \%$ sarcosyl in $100 \mathrm{ml}$ ) was mixed with the suspension, which was gently swirled until lysis was complete. Then $250 \mu \mathrm{l}$ of cold ammonium acetate $(7.5 \mathrm{M}$ aqueous solution) and $500 \mu \mathrm{l}$ of cold chloroform ( $96 \mathrm{ml}$ of chloroform, $4 \mathrm{ml}$ of 2-pentanol) were added to the suspension, and the whole mixture was shaken vigorously, transferred to microcentrifuge tubes, and centrifuged at high speed for $10 \mathrm{~min}$. The supernatant (approximately $740 \mu \mathrm{l}$ ) was transferred to a fresh microcentrifuge tube to which $410 \mu \mathrm{l}$ of cold isopropanol was added. The solution was mixed gently by inversion to precipitate the DNA as a pellet, and this pellet was washed three times in $70 \%$ ethanol and dried under a vacuum for $20 \mathrm{~min}$.

Hybridization was carried out by using the techniques described by Pitcher et al. (10) with an optimum reassociation temperature of $48^{\circ} \mathrm{C}$ for $16 \mathrm{~h}$ and a stringent washing temperature of $54^{\circ} \mathrm{C}$. DNA of the Providencia alcalifaciens type strain NCTC 10286 was used as a heterologous control $(\mathrm{G}+\mathrm{C}$ content, $43 \mathrm{~mol} \%)$ (6)

\section{RESULTS}

Cell morphology. Spiral cells of both $A$. succiniciproducens and $A$. thomasii were usually 0.6 to $0.8 \mu \mathrm{m}$ in diameter and 3 to $15 \mu \mathrm{m}$ long, although cells up to $32 \mu \mathrm{m}$ long were sometimes seen. The type strain of $A$. succiniciproducens was found to be pleomorphic with few typical spiral cells. Electron microscopy revealed the presence of bipolar tufts of flagella (Fig. 1).

Phenotypic characterization. All strains grew at 37 and $42^{\circ} \mathrm{C}$ but not at $22^{\circ} \mathrm{C}$. All strains were negative for catalase activity, oxidase activity, nitrate reduction, and hydrolysis of esculin, hippurate, and urea. Acid was produced from galactose, glucose, and maltose but not from cellobiose, mannitol, salicin sorbitol, and trehalose. As determined by the API ZYM kit, all of the strains produced leucine arylamidase and $N$-acetyl- $\beta$ glucosaminidase, but the following enzymes were not detected: alkaline phosphatase, esterase (C-4), esterase-lipase (C-8), lipase (C-14), valine arylamidase, cystine arylamidase, trypsin, chymotrypsin, phosphohydrolase, $\alpha$-D-galactosidase, $\beta$-glucuronidase, $\beta$-glucosidase, $\alpha$-mannosidase, and $\alpha$-fucosidase. The major products of glucose metabolism were succinic acid and acetic acid. Differences between the two species of the genus Anaerobiospirillum are shown in Table 2.

DNA base composition. Within $A$. succiniciproducens the $\mathrm{G}+\mathrm{C}$ contents were found to range from 42 to $44 \mathrm{~mol} \%$, and 
TABLE 1. Anaerobiospirillum strains used in this study

\begin{tabular}{|c|c|}
\hline Strain $^{a}$ & Source $^{b}$ \\
\hline \multicolumn{2}{|c|}{ A. succiniciproducens strains } \\
\hline \multicolumn{2}{|c|}{ NCTC $11536^{\mathrm{T}}$} \\
\hline \multicolumn{2}{|c|}{ A196/82 } \\
\hline \multicolumn{2}{|c|}{ 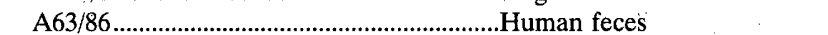 } \\
\hline \multicolumn{2}{|c|}{ 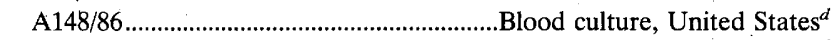 } \\
\hline \multicolumn{2}{|c|}{ A149/86 } \\
\hline \multicolumn{2}{|c|}{ A71/88 } \\
\hline \multicolumn{2}{|c|}{ A116/88 } \\
\hline \multicolumn{2}{|c|}{ 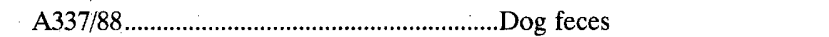 } \\
\hline \multicolumn{2}{|l|}{ A. thomasii strains } \\
\hline \multicolumn{2}{|c|}{ 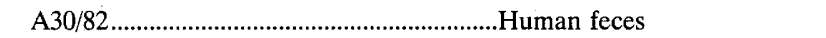 } \\
\hline \multicolumn{2}{|c|}{ 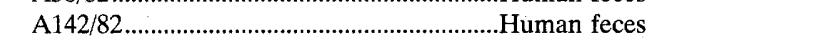 } \\
\hline \multicolumn{2}{|c|}{ 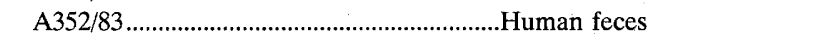 } \\
\hline \multicolumn{2}{|c|}{ 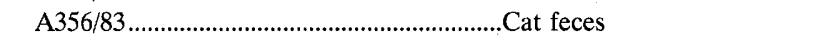 } \\
\hline \multicolumn{2}{|c|}{ 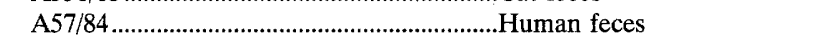 } \\
\hline \multicolumn{2}{|c|}{ 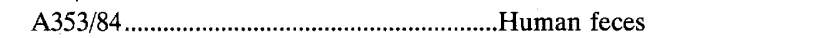 } \\
\hline \multicolumn{2}{|c|}{ A22/85 } \\
\hline \multicolumn{2}{|c|}{ 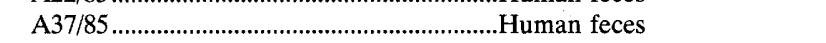 } \\
\hline \multicolumn{2}{|c|}{ 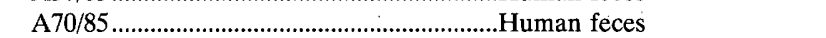 } \\
\hline \multicolumn{2}{|c|}{ 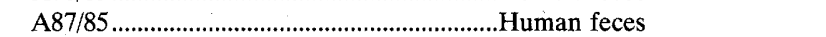 } \\
\hline \multicolumn{2}{|c|}{ 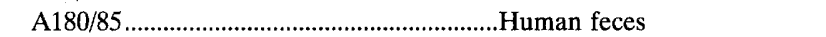 } \\
\hline \multicolumn{2}{|c|}{ 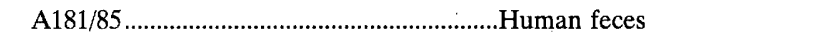 } \\
\hline \multicolumn{2}{|c|}{ 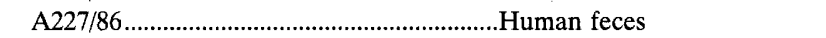 } \\
\hline \multicolumn{2}{|c|}{ 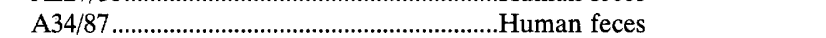 } \\
\hline A52/87 .................. & ......Dog feces \\
\hline $\mathrm{A} 114 / 87 \ldots \ldots \ldots \ldots . . . . . .$. & ......Dog feces \\
\hline 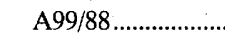 & ....Cat rectal swab \\
\hline A103/88 & ......Cat rectal swab \\
\hline 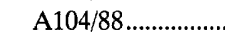 & ......Dog rectal swab \\
\hline A109/88.................... & ......Human feces \\
\hline A110/88 ................... & ....Human feces \\
\hline A115/88.................... & .....Cat rectal swab \\
\hline A117/88 & ......Cat rectal swab \\
\hline A118/88 .................... & ......Cat rectal swab \\
\hline A124/88.................. & ....Cat rectal swab \\
\hline A125/88 .................. & ...Cat rectal swab \\
\hline A126/88.................... & ......Cat rectal swab \\
\hline A137/88 & ......Cat rectal swab \\
\hline A138/88................. & ....Cat rectal swab \\
\hline $\mathrm{A} 150 / 88 \ldots \ldots \ldots \ldots$ & ....Cat rectal swab \\
\hline A151/88..................... & ....Dog rectal swab \\
\hline A152/88.................... & ......Dog rectal swab \\
\hline A153/88 .................. & ....Dog rectal swab \\
\hline A159/88................. & ....Dog rectal swab \\
\hline A160/88.................. & ....Cat rectal swab \\
\hline $\mathrm{A} 273 / 88^{\mathrm{T}}(=\mathrm{NCT}$ & ....Human feces \\
\hline 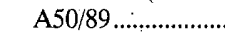 & ......Dog feces \\
\hline
\end{tabular}

${ }^{a}$ NCTC, National Collection of Type Cultures, London, United Kingdom; A National Collection of Type Cultures Identification Service, London, United Kingdom.

${ }^{b}$ All of the human isolates were obtained from different patients in the United Kingdom, and the cat and dog isolates were obtained from different animals examined at the same veterinary hospital, unless indicated otherwise (3)

${ }^{c}$ M. J. Hudson, Centre for Applied Microbiology and Research, Porton Down, United Kingdom.

${ }^{d}$ See reference 9 .

${ }^{e}$ See reference 12
A. thomasii had a $\mathrm{G}+\mathrm{C}$ range of 39 to $41 \mathrm{~mol} \%$ (Table 3 ). The $\mathrm{G}+\mathrm{C}$ contents of the $A$. thomasii strains not included in Table 3 were as follows: A181/85 and A137/88, 39 mol\%; A109/88, $\mathrm{A} 110 / 88$, and $\mathrm{A} 152 / 88,40 \mathrm{~mol} \%$; and $\mathrm{A} 70 / 85, \mathrm{~A} 159 / 88$, and A160/88, 41 mol\%.

DNA-DNA hybridization. The results of the DNA-DNA hybridization experiments are presented in Table 3. DNAs from A. succiniciproducens strains were 79 to $88 \%$ related to labeled DNA from type strain NCTC 11536, but the Anaerobiospirillum-like organisms were $5 \%$ or less related to the same type strain (most values were the same as the $<5 \%$ background value obtained with $P$. alcalifaciens NCTC $10286^{\mathrm{T}}$ [T $=$ type strain]). Hybridization with labeled probes prepared with DNAs from A151/88 and A273/88 ${ }^{\mathrm{T}}$ (Anaerobiospirillum-like organisms) demonstrated that DNAs from Anaerobiospirillumlike strains were $65 \%$ or more related to both DNA probes. The levels of hybridization between DNAs from $A$. succiniciproducens strains and A151/88 DNA varied from 3 to $12 \%$, and the levels of hybridization between DNAs from $A$. succiniciproducens strains and A273/88 ${ }^{\mathrm{T}}$ DNA ranged from 2 to $10 \%$.

The difference between the level of hybridization of probe DNA from A273/88 ${ }^{\mathrm{T}}$ with A151/88 DNA and the level of hybridization of probe DNA from A151/88 with A273/88 DNA was $5 \%$. The levels of hybridization for reciprocal pairs of labeled and unlabeled NCTC $11536^{\mathrm{T}}$ DNAs and A151/88 and $\mathrm{A} 273 / 88^{\mathrm{T}}$ DNAs varied between 2 and $7 \%$.

\section{DISCUSSION}

The original description of $A$. succiniciproducens, published in 1976, was based on three isolates from dogs (1). Since then, several cases of $A$. succiniciproducens bacteremia have been described $(5,9,12)$. However, when the type strain of $A$. succiniciproducens was compared with two strains isolated from humans with diarrhea, differences were noticed in the biochemical test results, and the type species was not able to grow on Skirrowl's Campylobacter isolation medium due to sensitivity to trimethoprim $(2,9)$. As additional strains isolated from human diarrheal feces were tested, it became clear that there was an undescribed Anaerobiospirillum species. The differences in phenotypic test results are shown in Table 2 . Although relatively few cases of Anaerobiospirillum infection have been described, there are possible differences in pathogenicity between the two species, as $A$. succiniciproducens has been isolated from blood cultures but $A$. thomasii has not. Lack of isolation of $A$. succiniciproducens from human diarrheal feces is probably due to the inability of this organism to grow on selective media normally used for isolation of Campylobacter strains and anaerobic bacteria in clinical laboratories.

I propose, because of the similarities in cell morphology, flagellar arrangement (bipolar tufts), growth characteristics, and some phenotypic characteristics and the differences in DNA-DNA hybridization values and DNA G $+\mathrm{C}$ contents of $A$. succiniciproducens and the Anaerobiospirillum-like organisms, that the definition of the genus Anaerobiospirillum be emended to include a new species, $A$. thomasii.

TABLE 2. Differentiation between $A$. succiniciproducens and $A$. thomasii

\begin{tabular}{|c|c|c|c|c|c|c|c|c|c|c|}
\hline \multirow{2}{*}{ Species } & \multirow{2}{*}{$\begin{array}{l}\text { No. of } \\
\text { strains }\end{array}$} & \multicolumn{6}{|c|}{ Acid production from: } & \multicolumn{3}{|c|}{ API substrates } \\
\hline & & Adonitol & Fructose & Inulin & Lactose & Raffinose & Sucrose & $\beta$-D-Galactoside & $\alpha$-D-Glucoside & $\alpha$-Maltoside \\
\hline A. succiniciproducens & 8 & $-^{a}$ & + & + & 7 & + & + & + & + & 4 \\
\hline A. thomasii & 37 & + & - & - & - & - & - & - & - & - \\
\hline
\end{tabular}

\footnotetext{
${ }^{a}-$, all strains are negative; + , all strains are positive. The numbers are the numbers of strains that are positive.
} 


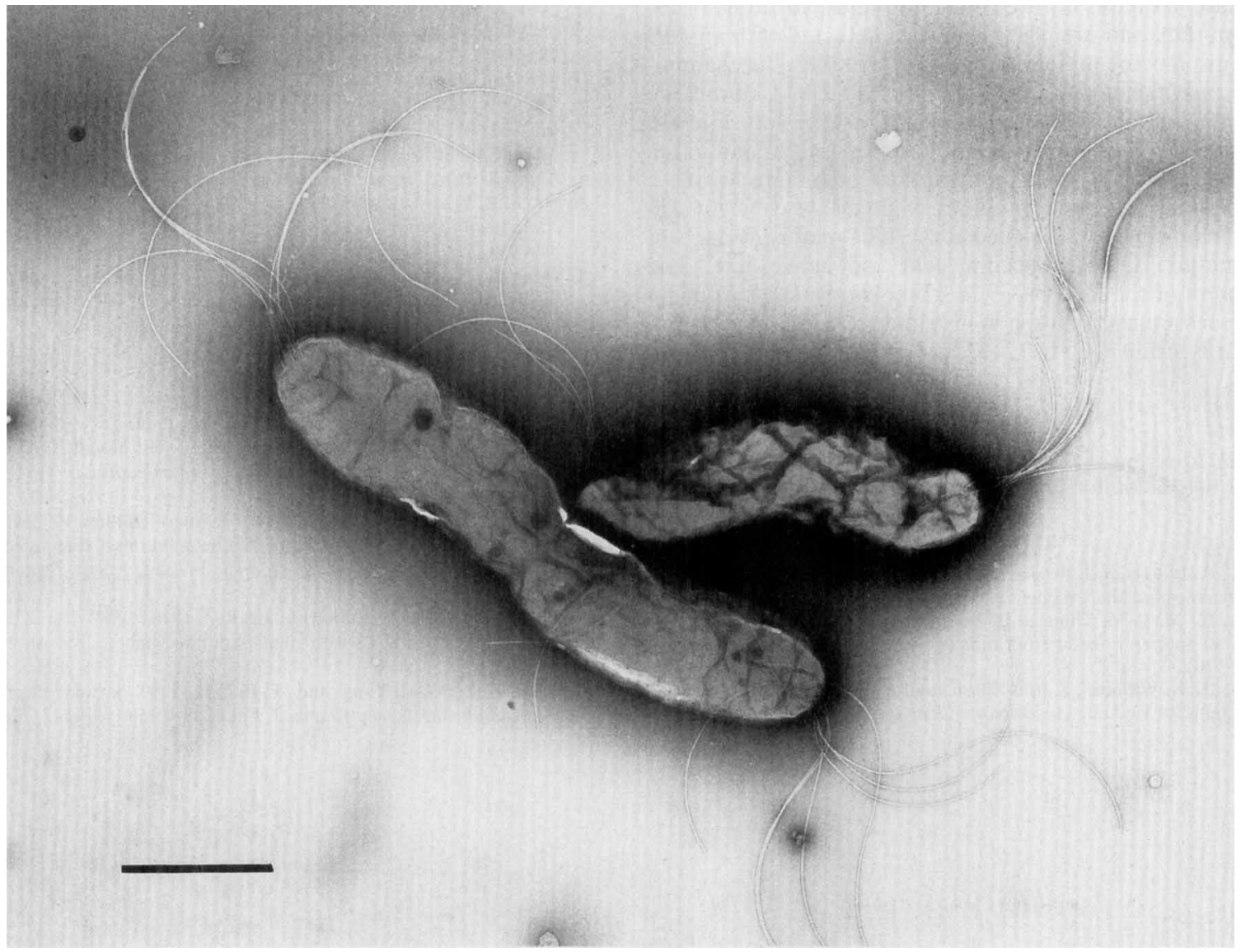

FIG. 1. Electron micrograph of negatively stained cells of $A$. thomasii NCTC $12467^{\mathrm{T}}$, showing bipolar tufts of flagella. Bar $=1 \mu \mathrm{m}$

It should be noted that the original description of $A$. succiniciproducens (1) stated that this organism is galactose negative. However, all of the strains tested in this study, including the type strain, were galactose positive.

Emended description of the genus Anaerobiospirillum Davis, Cleven, Brown, and Balish 1976. Gram-negative helical rods with rounded ends, usually 0.6 to $0.8 \mu \mathrm{m}$ in diameter and 3 to $15 \mu \mathrm{m}$ long, although some cells are up to $32 \mu \mathrm{m}$ long. Motile by means of bipolar tufts of flagella. Cells usually occur singly. Endospores are not formed. Strictly anaerobic. Catalase and oxidase negative. Does not hydrolyze esculin, hippurate, or urea and does not reduce nitrate. Carbohydrate metabolism is fermentative. The major products from glucose metabolism are succinic and acetic acids; traces of lactic and formic acids may also be formed. The optimal growth temperature is 37 to $42^{\circ} \mathrm{C}$. Found in feces of dogs and cats and as a pathogen in humans, causing septicemia and/or diarrhea. The DNA G $+\mathrm{C}$ content range is 39 to $44 \mathrm{~mol} \%$. The type species is $A$. succiniciproducens (type strain, NCTC 11536 [= ATCC 29305]).

Description of Anaerobiospirillum thomasii sp. nov. Anaerobiospirillum thomasii (thom'as.i.i. N. L. gen. n. thomasii, of Thomas, named after M. E. M. Thomas [Public Health Laboratory Service, 1947 to 1984], whose interest in and enthusiasm for uncommon medical bacterial infections led to the initiation of this study). Cells are gram-negative helical rods ( 0.5 to 0.7 by 5 to $32 \mu \mathrm{m}$ ). Flagella are arranged in bipolar tufts. Growth occurs at temperatures between 33 and $43^{\circ} \mathrm{C}$; the optimal temperature is $37^{\circ} \mathrm{C}$. Flat colonies with even, sometimes spreading edges are 1 to $2 \mathrm{~mm}$ in diameter after 24 to $48 \mathrm{~h}$ on horse blood agar. Hemolysis does not occur. Strictly anaerobic. Carbohy- drate metabolism is fermentative. Acid is produced from adonitol, galactose, glucose, and maltose. Acid is not produced from cellobiose, fructose, inulin, lactose, mannitol, raffinose, salicin, sorbitol, sucrose, and trehalose. The following tests are nega-

TABLE 3. DNA base compositions and levels of homology between $\left[{ }^{3} \mathrm{H}\right] \mathrm{dCTP}$-labeled DNAs and unlabeled DNAs

\begin{tabular}{|c|c|c|c|c|}
\hline \multirow{2}{*}{$\begin{array}{c}\text { Source of } \\
\text { unlabeled DNA }\end{array}$} & \multirow{2}{*}{$\begin{array}{c}\mathrm{G}+\mathrm{C} \\
\text { content } \\
(\mathrm{mol} \%)\end{array}$} & \multicolumn{3}{|c|}{$\begin{array}{c}\text { \% Homology with labeled } \\
\text { DNA from: }\end{array}$} \\
\hline & & NCTC $11536^{\mathrm{T}}$ & A151/88 & $\mathrm{A} 273 / 88^{\mathrm{T}}$ \\
\hline \multicolumn{5}{|l|}{ A. succiniciproducens strains } \\
\hline NCTC $11536^{\mathrm{T}}$ & 44 & 100 & 7 & 6 \\
\hline A196/82 & 44 & 88 & 5 & 9 \\
\hline A63/86 & $\mathrm{ND}^{b}$ & 81 & 7 & 10 \\
\hline A148/86 & 44 & 81 & 5 & 6 \\
\hline A71/88 & 42 & 79 & 3 & 2 \\
\hline A116/88 & ND & 80 & 12 & 6 \\
\hline \multicolumn{5}{|l|}{ A. thomasii strains } \\
\hline $\mathrm{A} 273 / 88^{\mathrm{T}}\left(=\right.$ NCTC $\left.12467^{\mathrm{T}}\right)$ & 41 & 4 & 97 & 100 \\
\hline A52/87 & ND & 4 & 103 & 93 \\
\hline A117/88 & 39 & 3 & 97 & 97 \\
\hline A227/86 & 41 & 2 & 102 & 101 \\
\hline A114/87 & 40 & 0 & 82 & 70 \\
\hline A $138 / 88$ & 41 & 5 & 65 & 77 \\
\hline A151/88 & $\mathrm{ND}$ & 2 & 100 & 92 \\
\hline
\end{tabular}

${ }^{a}$ The level of hybridization between $P$. alcalifaciens NCTC $10286^{\mathrm{T}}$ and each probe was less than $5 \%$.

${ }^{b} \mathrm{ND}$, not determined. 
tive: catalase, oxidase, nitrate reduction, and hydrolysis of esculin, hippurate, and urea. The enzymes detected with an API ZYM kit are leucine arylamidase and $N$-acetyl- $\beta$-glucosaminidase. The enzymes not detected with an API ZYM kit include acid and alkaline phosphatases, esterase (C-4), esterase-lipase (C-8), lipase (C-14), valine arylamidase, cystine arylamidase, trypsin, chymotrypsin, phosphohydrolase, $\alpha$-D-galactosidase, $\beta$-D-galactosidase, $\beta$-glucuronidase, $\alpha$-glucosidase, $\beta$-glucosidase, $\alpha$-mannosidase, and $\alpha$-fucosidase. The major products of glucose metabolism are succinic acid and acetic acid. The $\mathrm{G}+\mathrm{C}$ content of the DNA is 39 to $42 \mathrm{~mol} \%$. Isolated from cat and $\operatorname{dog}$ feces and as a pathogen in human diarrheal feces. The type strain is strain NCTC 12467.

\section{ACKNOWLEDGMENTS}

I thank H. Appelton of the Virus Reference Division and E. Paddon of Medical Illustration for the electron micrographs.

\section{REFERENCES}

1. Davis, C. P., D. Cleven, J. Brown, and E. Balish. 1976. Anaerobiospirillum, a new genus of spiral-shaped bacteria. Int. J. Syst. Bacteriol. 26:498-504.

2. Malnick, H., M. E. M. Thomas, H. Lotay, and M. Robbins. 1983. Anaerobiospirillum species isolated from humans with diarrhoea. J. Clin. Pathol. 36:1097-1101.

3. Malnick, H., K. Williams, J. Phil-Ebosie, and A. S. Levy. 1990. Description of a medium for isolating Anaerobiospirillum spp., a possible cause of zoo- notic disease, from diarrheal feces and blood of humans and use of the medium in a survey of human, canine, and feline feces. J. Clin. Microbiol. 28:1380-1384.

4. Marmur, J., and P. Doty. 1962. Determination of the base composition of deoxyribonucleic acid from its thermal denaturation temperature. J. Mol Biol. 5:109-118.

5. McNeil, M. M., W. J. Martone, and V. R. Dowell, Jr. 1987. Bacteremia with Anaerobiospirillum succiniciproducens. Rev. Infect. Dis. 9:737-742.

6. Owen, R. J., A. U. Ahmed, and C. A. Dawson. 1987. Guanine-plus-cytosine contents of type strains of the genus Providencia. Int. J. Syst. Bacteriol. 37: 449-450.

7. Owen, R. J., and P. Borman. 1987. A rapid biochemical method for purifying high molecular weight bacterial chromosomal DNA for restriction enzyme analysis. Nucleic Acids Res. 15:3631.

8. Owen, R. J., and D. Pitcher. 1985. Current methods for estimating DNA base composition and levels of DNA-DNA hybridization, p. 67-93. In M. Goodfellow and D. E. Minnikin (ed.), Chemical methods in bacterial systematics. Academic Press, Inc., London, United Kingdom.

9. Park, C. H., D. L. Hixon, J. F. Endlich, P. O'Connell, F. T. Bradd, and P. M. Mount. 1986. Anaerobiospirillum succiniciproducens. Two case reports. Am. J. Clin. Pathol. 85:73-76.

10. Pitcher, D., A. Soto, F. Soriano, and P. Valero-Guillen. 1992. Classification of coryneform bacteria associated with human urinary tract infection (group D2) as Corynebacterium urealyticum sp. nov. Int. J. Syst. Bacteriol. 42:178181

11. Pitcher, D. G., N. A. Saunders, and R. J. Owen. 1989. Rapid extraction of bacterial genomic DNA with guanidium thiocyanate. Lett. Appl. Microbiol. 8:151-156.

12. Yuen, K.-Y., W.-H. Yung, and W.-H. Seto. 1989. A case report of Anaerobiospirillum causing septicemia. J. Infect. Dis. 159:153-154. 